\title{
Functional Asymmetries in Visual Pathways Carrying S-Cone Signals in Macaque
}

\author{
Chris Tailby, ${ }^{1 \star}$ Samuel G. Solomon, ${ }^{2 *}$ and Peter Lennie ${ }^{1,3}$ \\ ${ }^{1}$ Center for Neural Science, New York University, New York, New York 10003, ${ }^{2}$ Bosch Institute and School of Medical Sciences, The University of Sydney, \\ New South Wales, 2006, Australia, and ${ }^{3}$ Center for Visual Science and the Department of Brain and Cognitive Sciences, University of Rochester, Rochester, \\ New York 14627
}

In the lateral geniculate nucleus of macaque, we recorded from neurons with substantial input from S-cones and found that, on several important dimensions, the properties of neurons that receive inhibitory input from S-cones ("S - ") are quite unlike those of neurons that receive excitatory input from S-cones ("S+"). First, the organization of chromatic inputs differs substantially: in S+ cells, S-cone signals were usually opposed by those of L- and M-cones; in S- cells, signals from L-cones were usually opposed to those of S- and M-cones. Second, to pure $S$-cone modulation, $S+$ cells are twice as sensitive as $S$ - cells, but $S$ - cells were much more susceptible to contrast adaptation. Third, in $S-$ cells but not $S+$ cells, the spatial frequency resolution for achromatic modulation was often greater, the tuning curve and more bandpass, than that for S-cone modulation. Along the dimensions on which we measured, the properties of the $S+$ cells were relatively tightly clustered, suggesting a homogenous class. Although the chromatic properties of $S-$ cells are heterogeneous, the distribution of their tuning along other stimulus dimensions does not suggest multiple subtypes.

Key words: vision; color; macaque; LGN; parallel pathways; S-cone; blue cone

\section{Introduction}

Mechanisms that compare the signals of cone photoreceptors provide the capacity for color vision. Two are presumed to exist in humans and Old World primates, one sensitive to red-green color variation and the other to yellow-blue variation. The probable neural substrate of the mechanism sensitive to red-green variation is the parvocellular $(\mathrm{P})$ pathway that originates in the retina and conveys signals through the lateral geniculate nucleus (LGN) to cortex. P-cells carry signals of opposite sign from the long-wavelength (L) and middle-wavelength (M) sensitive cones. Two complementary types exist, one in which the signals from $\mathrm{L}$ cones excite the cell and signals from $\mathrm{M}$ cones inhibit it, and another type in which the polarities of signals are reversed (De Valois et al., 1966, 2000; Wiesel and Hubel, 1966; Derrington et al., 1984; Smith et al., 1992; Lankheet et al., 1998; White et al., 1998) (but see Rodieck, 1988; Calkins and Sterling, 1999).

Comparatively less is known about the substrate of the mechanism that signals the yellow-blue dimension of color variation and that must draw substantial input from S-cones. One cell type $(\mathrm{S}+)$ opposes excitatory input from S-cones to a combined inhibitory signal from L- and M-cones (Derrington et al., 1984;

\footnotetext{
Received Aug. 2, 2007; revised March 3, 2008; accepted March 4, 2008.

This work was supported by National Institutes of Health Grants EY04440 and EY13079 and Australian National Health and Medical Research Council Grant 211247 (S.G.S.). We thank N. Dhruv, S. Sokol, and N. Majaj for assistance in experiments and, along with J. Krauskopf, for helpful discussions.

${ }^{*}$ C.T. and S.G.S. contributed equally to this work.

Correspondence should be addressed to Chris Tailby, National Vision Research Institute of Australia, Department of Optometry and Vision Sciences, University of Melbourne, Corner of Keppel and Cardigan Streets, Carlton, Victoria 3053, Australia. E-mail: ctailby@unimelb.edu.au.

DOI:10.1523/JNEUROSC1.5338-07.2008

Copyright $\odot 2008$ Society for Neuroscience $\quad 0270-6474 / 08 / 284078-10 \$ 15.00 / 0$
}

Dacey and Lee, 1994; White et al., 1998; Silveira et al., 1999; Reid and Shapley, 2002; Chatterjee and Callaway, 2003; Field et al., 2007). Another, seldom encountered, cell type (S-) draws inhibitory input from S-cones (Kruger, 1977; Malpeli and Schiller, 1978; de Monasterio, 1979; Zrenner and Gouras, 1981; Zrenner et al., 1983; Derrington et al., 1984; Valberg et al., 1986; Reid and Shapley, 2002; Chatterjee and Callaway, 2003; Dacey and Packer, 2003; Szmajda et al., 2006). Recent work on retina has shown that ganglion cells that receive $S-$ input are morphologically quite unlike those that receive S+ input (Dacey and Packer, 2003; Dacey et al., 2003, 2005). We show here that the functional characteristics of $S-$ neurons in LGN differ substantially from those of the better-understood S+ neurons. The S+ and S- pathways lack the symmetrical relationship that characterizes the ONcenter and OFF-center divisions of the P-pathway.

\section{Materials and Methods}

Single-unit recordings were made from the LGN in 13 anesthetized, paralyzed male Macaca fascicularis, prepared as described by Solomon and Lennie (2005). All procedures conformed to the guidelines approved by the New York University Animal Welfare Committee. A craniotomy $10 \mathrm{~mm}$ in diameter was made over the right LGN, and a guide tube containing the electrode (tungsten-in-glass) (Merrill and Ainsworth, 1972) was placed stereotaxically with its tip 3-5 mm above the LGN. The dura was covered with warm agar, and the craniotomy was sealed with dental acrylic. The receptive field position of an isolated neuron was initially plotted on a tangent screen; a mirror was then interposed in the optic axis to bring the receptive field onto a calibrated monitor [Sony (Tokyo, Japan) G500 or Iiyama (Tokyo, Japan) Vision Master Pro 514] that was refreshed with a frame rate of 90 or $200 \mathrm{~Hz}$. The monkey viewed the screen through dilated pupils ( $\sim 7 \mathrm{~mm}$ diameter), and no artificial pupils were used; supplementary lenses were used to focus the eyes at the 
viewing distance of $114 \mathrm{~cm}$. At the beginning of the experiment and at regular intervals afterward, the positions of the foveas were mapped by reverse ophthalmoscopy.

Visual stimuli. The stimulus was a drifting sinusoidal grating or spatially uniform field modulated in time, presented within a circular window $8^{\circ}$ in diameter. The remainder of the screen was held at the mean luminance and chromaticity $\left[\sim 50 \mathrm{~cd} / \mathrm{m}^{-2}\right.$; CIE (Commission Internationale de l'Éclairage, 1931) $x, y$ of $\sim 0.30,0.32]$. All stimuli were produced by spatiotemporal modulation around this point. These modulations can be represented in a three-dimensional color space described previously (Derrington et al., 1984; Lennie et al., 1990). Along the L-M axis, only the signals from L- and M-cones vary, in opposition, without variation in luminance. Along the orthogonal S-cone-isolating axis, there is no modulation of either the $\mathrm{L}$ - or $\mathrm{M}$-cones. The $\mathrm{L}-\mathrm{M}$ and $\mathrm{S}$ axes define a plane in which only chromaticity varies. Normal to this plane is the achromatic axis along which the signals from all three cone classes vary in proportion. Throughout, we use the term "contrast" to specify the amplitude of modulation relative to the maximum achievable along these three principal axes. We use the term "cone contrast" explicitly whenever we specify modulation of the activity in a particular class of cone. Full modulation along the $\mathrm{L}-\mathrm{M}$ axis gave cone contrasts of 0.08 for the L-cones and 0.15 for the M-cones. Full modulation along the $\mathrm{S}$ axis produced a cone contrast of 0.85 for the S-cones. When making measurements, the stimuli in a set (one of which was always a blank screen) were presented in random order, each 4-20 times (average equals 8), in trials lasting $2 \mathrm{~s}$. Between trials, the screen was blank (at the mean luminance) for $0.5 \mathrm{~s}$. From the train of impulses discharged during each stimulus presentation, we extracted the amplitude of the Fourier component at the frequency of stimulation. The first $150 \mathrm{~ms}$ of response was always discarded from the analysis.

Estimating cone inputs to receptive fields. We identified the types and signs of the cone signals driving each unit by measuring responses during square-wave modulation of a spatially uniform field at $0.5 \mathrm{~Hz}$ (see Fig. 1). Stimuli were modulated at the maximum achievable contrast along color directions that isolated each of the cone types, providing $\mathrm{L}_{-}, \mathrm{M}-$, and S-cone contrasts of $\sim 0.17, \sim 0.17$, and $\sim 0.85$, respectively.

We quantitatively determined the chromatic signatures of receptive fields from the responses to several color directions (vectors) in the space described above. If a receptive field combines cone signals linearly, then the response to any vector is the inner product of the stimulus vector and the preferred color vector of the cell, such that

$$
S=K\left[\sin (\theta) \cdot \sin \left(\theta_{m}\right)+\cos (\theta) \cdot \cos \left(\theta_{m}\right) \cdot \cos \left(\phi-\phi_{m}\right)\right],
$$

where $S$ is the sensitivity of the cell to the color direction (response amplitude divided by the contrast along the vector), $K$ is the gain, $\theta$ and $\phi$ are the elevation and azimuth of the stimulus vector, and $\theta_{\mathrm{m}}$ and $\phi_{\mathrm{m}}$ are the elevation and azimuth of the preferred color vector of the cell. The sign of the response to a particular direction of modulation is given by the response phase. From the preferred color directions of Equation 1, we can derive the relative weights the cell assigns to the signals from each of the cone classes (Lennie et al., 1990). We used chromatic calibrations based on the cone fundamentals of Smith and Pokorny (1975) with the influence of the macular pigment removed according to the density spectrum provided by Stockman et al. (1999). Macular pigment density falls to $<10 \%$ of its peak at $\sim 4^{\circ}$ eccentricity and is completely absent beyond $\sim 6.5^{\circ}$ (Snodderly et al., 1991). The most foveal receptive field in our sample lay at $3.9^{\circ}$ eccentricity, two others lay between 4 and $5^{\circ}$, and an additional five lay between 5 and $6.5^{\circ}$; the mean receptive field eccentricity of all $101 \mathrm{~S}+$ and $\mathrm{S}-$ units was $15^{\circ}$. Conversion matrices for converting from DKL space (color space introduced by Derrington et al., 1984) to red-green-blue (RGB) units, and from LMS cone contrast space to RGB units, were derived using standard methods (Brainard, 1996).

Contrast adaptation (habituation). We measured the effect of contrast adaptation (habituation) on responses to modulation at several contrasts along a single color direction or to several color directions at a single contrast. All stimuli were temporally modulated uniform fields. We first measured the unadapted contrast response function (along the S-cone axis for $\mathrm{S}+$ and $\mathrm{S}-$ cells, along the $\mathrm{L}-\mathrm{M}$ axis for P-cells) and from this identified the minimum contrast to which the cell was responsive $\left(C_{\min }\right)$, and a contrast at the upper end of its linear contrast-response range $\left(C_{\max }\right)$. To determine the effect of habituation on the contrast response function, we presented logarithmically spaced contrasts between $C_{\text {min }}$ and 0.9 ; its effect on azimuth tuning function was determined by measuring response to eight vectors within the isoluminant plane presented at $C_{\max }$. In both cases, responses were obtained before, during, and after habituation to modulation along one color vector.

In making measurements before and after recovery to habituation, each test stimulus was presented for $1 \mathrm{~s}$, with $4 \mathrm{~s}$ of blank screen between presentations. In making measurements during habituation, each test stimulus was presented for $1 \mathrm{~s}$, separated by $4 \mathrm{~s}$ habituation, after an initial habituating period of $30 \mathrm{~s}$. We usually obtained responses to 10 presentations of each test stimulus. For each cell, we combined the measurements made before and after recovery and compared this combined "unadapted" measure with that obtained in the adapted state. All unadapted runs were preceded by $\sim 5$ min of exposure to a blank screen.

For LGN neurons, the response $R$, as a function of contrast $c$, is well described by

$$
R=R_{\max } \frac{c}{c_{50}+c},
$$

where $R_{\max }$, the maximum response, can be understood to represent response gain, and $c_{50}$, the contrast for half-maximum response, can be understood as a measure of contrast sensitivity. We fit two different constrained versions of this model to the observed responses, one in which only the $c_{50}$ term was free to vary between the adapted and unadapted states (amounting to changes in contrast sensitivity), and one in which only the $R_{\max }$ term was allowed to vary (amounting to changes in response gain). Contrast gain was calculated as $R_{\max } / c_{50}$.

Spatial and temporal tuning. To measure the spatial frequency tuning, we presented gratings drifting at $5 \mathrm{~Hz}$. The spatial frequency was varied in equal logarithmic steps around an initial estimate of the preferred frequency. The stimulus set included a spatially uniform field modulated in time (spatial frequency 0 ). We measured temporal-frequency tuning using the same procedure with the spatial frequency of the stimulus held constant at the preferred value; temporal frequency ranged in equal logarithmic steps from 0.5 to $50 \mathrm{~Hz}$. Spatial and temporal tuning along different color directions were measured in separate experimental blocks. All stimuli were presented at the maximum achievable contrast within the gamut of the monitor (see above, Visual stimuli).

The ranges of spatial and temporal frequencies used in measurements varied from cell to cell. To generate the averaged tuning curves plotted in Figures 6 and 7, we assembled the full set of $n$ spatial/temporal frequencies and their associated responses, measured across all $x$ cells of a given class (S+ or $\left.\mathrm{S}^{-}\right)$into an $n x \times 2$ matrix. A given row in this matrix contained the spatial/temporal frequency $n_{i}$ shown to cell $x_{i}$ and the response of that cell to that frequency. The rows of this matrix were then sorted in ascending order by spatial/temporal frequency, and the matrix was subdivided into eight samples by taking each nonoverlapping segment of $n / 8$ rows. The geometric mean spatial/temporal frequency and the mean response, along with their associated SEMs, were calculated for each of these eight samples and are plotted in Figures 7 and 8.

Direction tuning was calculated from responses to a set of eight drifting gratings (direction varied in steps of $45^{\circ}$ ). The direction-selectivity index (DSI) was determined from these response measurements by the following circular variance:

$$
D S I=1-\left[\frac{\sum_{k} r_{k} \exp \left\{i 2 \pi \theta_{k} / 360\right\}}{\sum_{k} r_{k}}\right],
$$

where $\theta_{k}$ is grating direction (in degrees) and $r_{k}$ is the response to that direction. A value of 1 indicates response to only one direction of motion, and a value of 0 indicates the equal responses to all directions.

\section{Results}

The observations described here deal with 97 neurons that received substantial input from $\mathrm{S}$-cones. They had receptive fields 
located at eccentricities between 3.9 and $29.6^{\circ}$ (mean of $15.0^{\circ}$ ). These neurons were among 469 characterized in the course of a larger set of studies on LGN.

\section{Identifying neurons driven by S-cones}

We obtained an initial estimate of the signs and types of cone inputs to each cell by measuring responses to square-wave temporal modulation of a spatially uniform field along directions in color space that isolated activity in the L-cones (Fig. 1, top row), M-cones (middle row), and S-cones (bottom row). Figure $1 A$ shows the responses of a cell (which we will call $\mathrm{S}+$ ) that was excited by increments in S-cone activation and by decrements in $\mathrm{L}$ - or M-cone activation (Derrington et al., 1984; Smith et al., 1992); Figure $1 B$ shows responses of a cell (which we will call $\mathrm{S}-$ ) that was excited by decrements in S-cone activation or M-cone activation and by increments in L-cone activation. For comparison, the P-cell in Figure $1 C$ shows large and opposite responses to modulation of the L- and $\mathrm{M}$-cones and no response to modulation of the S-cones.

Most retinal ganglion cells and LGN cells sum cone signals linearly (Derrington et al., 1984; Smith et al., 1992; Reid and Shapley, 2002), and this was true for both $\mathrm{S}+$ and $\mathrm{S}-$ cells. Figure $2, A$ and $B$, shows the responses of the $S+$ and $S-$ cell shown in Figure 1, $A$ and $B$, respectively, to sinusoidal temporal modulation of a spatially uniform field along a series of vectors in a three-dimensional color space described in Materials and Methods. The top panels show responses to stimuli modulated along vectors in the isoluminant plane defined by an axis of $\mathrm{L}-\mathrm{M}$ modulation (azimuth $0-180^{\circ}$ ) and an axis of pure S-cone modulation (azimuth $90-270^{\circ}$ ). The middle and bottom panels of Figure 2 show responses to stimuli along vectors in two other planes of the color space, one formed by the achromatic axis (elevation $90^{\circ}$ ) and the L-M axis, the other formed by the achromatic axis and the $\mathrm{S}$-cone axis. $\mathrm{S}+$ and $\mathrm{S}-$ cells respond quite differently to stimulus modulations within the isoluminant plane. Insets show averaged responses, folded to one cycle of modulation, for selected directions in each plane. The $\mathrm{S}+$ cell responds robustly to $S$-cone modulation (azimuth $90^{\circ}$ ) and not at all to $\mathrm{L}-\mathrm{M}$ modulation (azimuth $0^{\circ}$ ). The $\mathrm{S}-$ cell responds to modulation along both the L-M- and S-cone directions but not at all to modulation along the $-45^{\circ}$ direction. Responses to modulation out of the isoluminant plane were generally stronger in $\mathrm{S}-$ cells than $\mathrm{S}+$ cells. For both $\mathrm{S}+$ and $\mathrm{S}-$ cells, the responses were well described by a linear model of cone summation (smooth lines; see Materials and Methods). The model explained on average $88.0 \%$ of the response variance in S+ cells and $90.1 \%$ in $\mathrm{S}$ - cells (in P-cells, the model explained 88.0\%).

From the fit of the model, we extracted the preferred vector of each cell in the three-dimensional color space and the weights and signs of its cone inputs (Derrington et al., 1984; Lennie et al., 1990). Figure $3 A$ shows the distribution of preferred directions of
B $\quad C$
S- cell
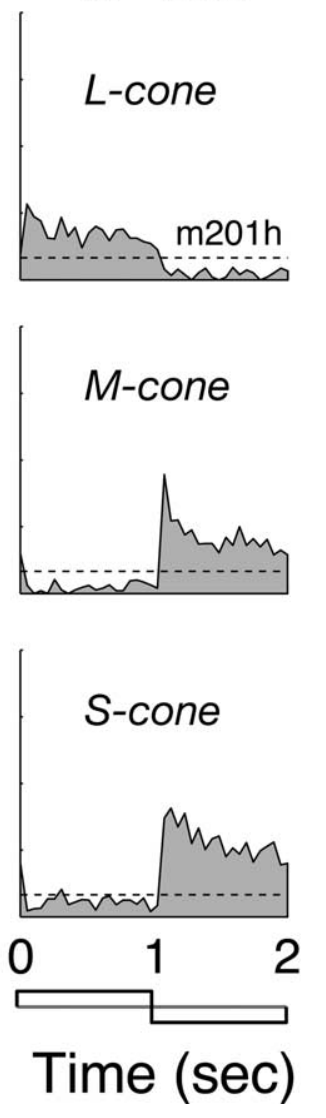

P-cell
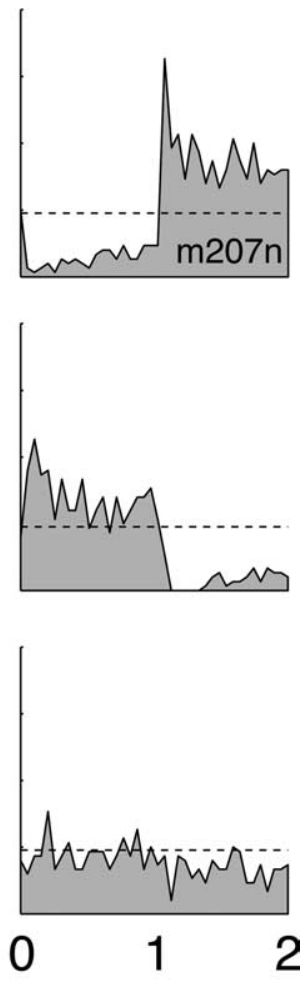

Figure 1. Cone inputs to the receptive fields of macaque LGN cells. $\boldsymbol{A}$, Cell excited by increments in $S$-cone activation $(S+) . \boldsymbol{B}$, Cell excited by decrements in $S$-cone activation $(S-)$. C, P-cell. Each panel shows a peristimulus time histogram of discharge during square-wave modulation of a spatially uniform field (temporal frequency of $0.5 \mathrm{~Hz}$; diameter of $8^{\circ}$ ). Responses have been folded to one cycle of modulation and are the average of at least six cycles. Panels in each row show, from top to bottom, responses to modulation of $\mathrm{L}$-cones alone, $\mathrm{M}$-cones alone, and $\mathrm{S}$-cones alone. Dashed line shows maintained discharge.

all neurons except magnocellular cells. The histogram below the scatter plot shows the distribution of preferred directions in the isoluminant plane. Previous work might lead us to expect four modes in this distribution: at $0^{\circ}(+\mathrm{L}-\mathrm{M})$ and $180^{\circ}(+\mathrm{M}-\mathrm{L})$, corresponding to P-cells, and at $270^{\circ}(+\mathrm{S})$, and $90^{\circ}(-\mathrm{S})$. The first three modes are clearly represented, but in the region between $\sim 30^{\circ}$ and $\sim 110^{\circ}$, in which cells must receive inhibitory $\mathrm{S}$-cone input, there is considerable scatter in the histogram, with small modes at 45 and $90^{\circ}$. In what follows, we consider only cells for which S-cones provided at least $10 \%$ of the total weight of cone inputs. This criterion admitted $53 \mathrm{~S}+$ neurons and $44 \mathrm{~S}-$ neurons. Our data set includes three additional $\mathrm{S}+$ and one additional S- cell for which we did not collect the full set of measurements described above but which were unambiguously identified on the basis of responses to cone- isolating steps (as in Fig. $1)$.

\section{Cone inputs and contrast sensitivity}

Figure $3 B$ shows, for the cells represented in Figure $3 A$, the normalized weights given to inputs from the three types of cones. The relative weight of $\mathrm{L}$-cone input is plotted against that of $\mathrm{M}$-cones, so points on the diagonals would represent cells that received no $\mathrm{S}$-cone input. The relative magnitude of S-cone input is represented by the distance of a point from a unit diagonal; its sign is 


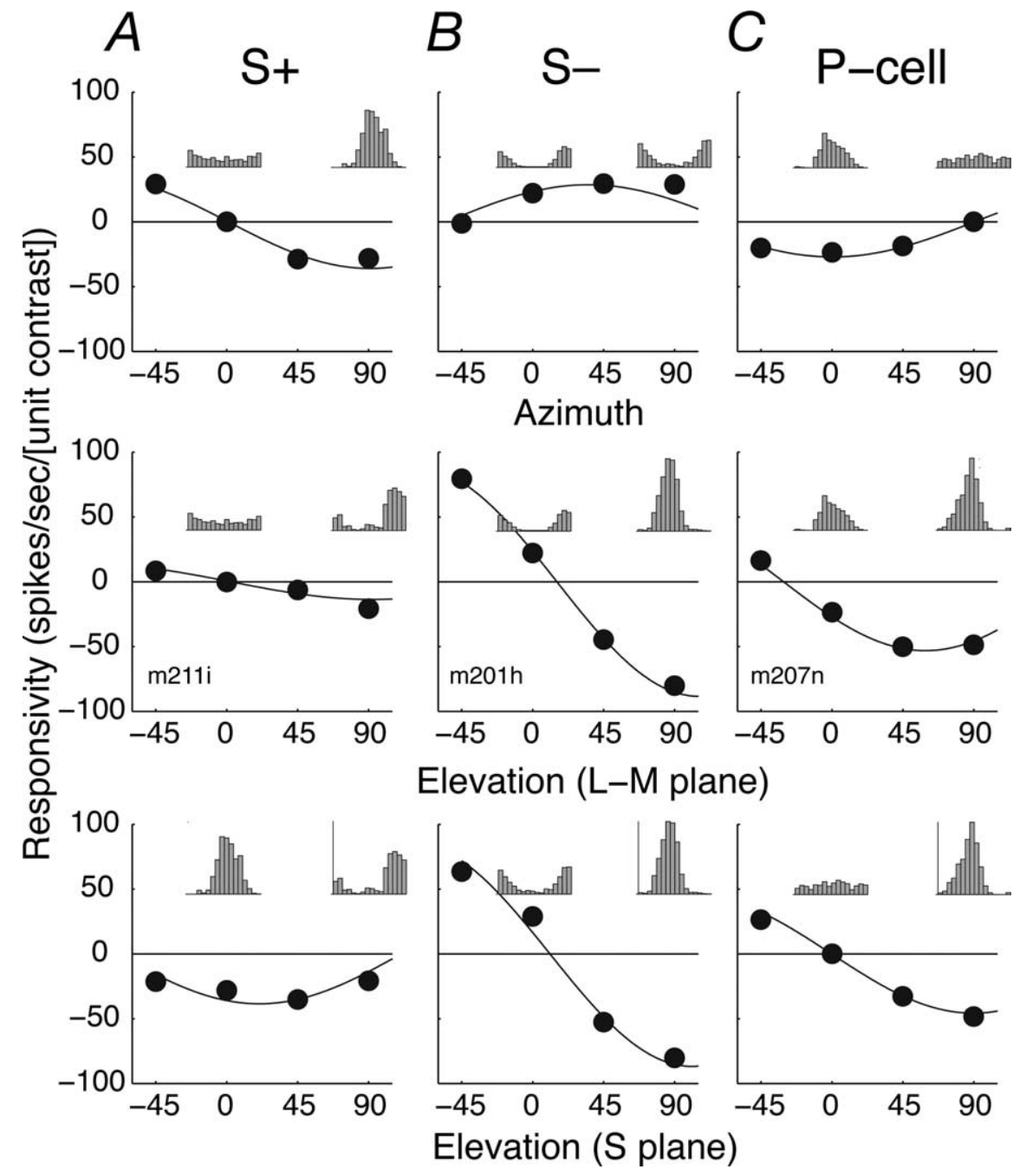

Figure 2. Responses of $S+, S-$, and P-cells to stimulus modulation in a three-dimensional color space. $A, S+$ cell. $B, S-$ cell. C, P-cell. Same cells as in Figure 1. The top panels show the amplitude of response (the Fourier harmonic of the discharge at the temporal frequency of stimulation) as a function of angle (azimuth) in the isoluminant plane (elevation $0^{\circ}$ ). The middle panels show responses as a function of angle (elevation) in the plane formed by the $L-M$ axis (azimuth $0^{\circ}$ ) and the achromatic axis (elevation $90^{\circ}$ ). Bottom panels show responses as a function of angle (elevation) in the plane formed by the $\mathrm{S}$-cone axis (azimuth $90^{\circ}$ ) and the achromatic axis. The sign of the response is determined by its phase. SEMs are all smaller than the data points. The smooth lines show for each cell the best-fitting prediction of a linear model of cone summation described in Materials and Methods. Insets in each panel show the average responses to one cycle of modulation for stimuli modulated along $0^{\circ}$ (left) and $90^{\circ}$ (right) in the relevant chromatic plane (calibration in $A, 75$ spikes/s; $B, 160$ spikes/s; $\boldsymbol{C}, 115$ spikes/s). The stimulus was a spatially uniform field (diameter of $8^{\circ}$ ) modulated sinusoidally in time at $5 \mathrm{~Hz}$.

represented by the type of point (open circle, $\mathrm{S}+$; filled circle, $\mathrm{S}-$ ).

In both $\mathrm{S}+$ and $\mathrm{S}-$ cells, the signals of the L-cones were almost always opposed to those of the S-cones, but the signals of $\mathrm{M}$-cones could add to or oppose those of the S-cones. S+ cells mostly received inputs of the same sign from $\mathrm{L}$ - and $\mathrm{M}$-cones, opposed to strong input from S-cones (normalized S-weight > 0.35 ); their chromatic preferences were sharply aligned with the $\mathrm{S}$-cone axis. Figure 3 suggests that $\mathrm{S}-$ cells fall into two groups that differ in the strength of their S-cone inputs. Some $S-$ cells were like $S+$ cells with inverted inputs and had exactly the opposite chromatic preferences. However, most $\mathrm{S}-$ cells received comparatively weak S-cone input (unsigned normalized S-weight $<0.35$ ) and received inputs of opposite sign from Land $\mathrm{M}$-cones (with input from $\mathrm{M}$-cones mostly having the same sign as that from S-cones). As a result, their preferred azimuths lay intermediate to the $\mathrm{L}-\mathrm{M}$ and $\mathrm{S}$ axes. Beyond the signs and weights of cone inputs, there were no other indications of distinct subgroups of $\mathrm{S}-$ neurons (see below, Subclasses of S- cell?), so we do not distinguish them in the subsequent comparisons with $\mathrm{S}+$ cells. Bootstrap analysis of these data confirmed that the chromatic signatures of individual cells were reliable. The average SDs of the normalized L-, M-, and $\mathrm{S}$-cone weights were, respectively, $0.074,0.087$, and 0.051 for $\mathrm{S}+$ cells and $0.086,0.063$, and 0.048 for $S-$ cells. Figure $3 C$ shows typical cone weight distributions returned by the bootstrap analysis for five $\mathrm{S}-$ cells; $D$ shows the same for five $\mathrm{S}+$ cells.

The unsigned normalized weight of signals from S-cones was generally less in Scells (mean $\pm \mathrm{SD}, 0.32 \pm 0.21 ; n=44$ ) than in $S+$ cells (mean $\pm \mathrm{SD}, 0.56 \pm 0.11$; $n=53 ; p<0.01$, Kruskal-Wallis test). This suggests that the $\mathrm{S}-$ cells might be less sensitive to S-cone modulation. To determine this, we measured contrast-response functions using pure S-cone modulation. Figure 4 shows the average curves for the two groups of cells. $\mathrm{S}+$ cells were much more sensitive, and their responses saturated at higher contrasts (without any accompanying phase advance) (Yeh et al., 1995; Solomon and Lennie, 2005). The contrast gain (see Materials and Methods) of S+ cells was twice that of S- cells (respectively, 61.9 and 28.9 impulses per second per unit contrast). As might be expected from the different distributions of their preferred color directions (Fig. 3A), Scells were more sensitive than $\mathrm{S}+$ cells to achromatic modulation (38.0 and $27.0 \mathrm{im}$ pulses per second per unit contrast, respectively) (data not shown). S+ cells and Scells differed also in their maintained discharge rates to a uniformly illuminated screen ( $0 \%$ contrast): 22.9 spikes per second for S+ vs 12.7 for $S-$ cells $(p<0.05$, Kruskal-Wallis). No similar differences exist among subtypes of P-cells or M-cells (Troy and Lee, 1994).

In $\mathrm{S}-$ cells, but not $\mathrm{S}+$ cells, contrast sensitivity could be reduced by prolonged exposure (habituation) to $S$-cone modulation. Figure $5 A$ shows that, after prolonged exposure to an habituating stimulus (see Materials and Methods), the responses of $\mathrm{S}$ - cells were substantially reduced over the full range of contrasts; in S+ cells (Fig. 5B), habituation brought about only a slight reduction in responses at high contrasts. We characterized the changes in sensitivity by fitting Naka-Rushton functions to the contrast-response curves obtained before and during habituation (see Materials and Methods). For S+ cells, the slight impact of habituation could be equally well explained by supposing a small reduction in response gain (average of $13 \% ; n=7$ ) or by a small reduction in contrast sensitivity (an increase in $c_{50}$ of $19 \%$ ). Responses of S - cells did not saturate, so changes during habituation could be equally well described by loss of response 

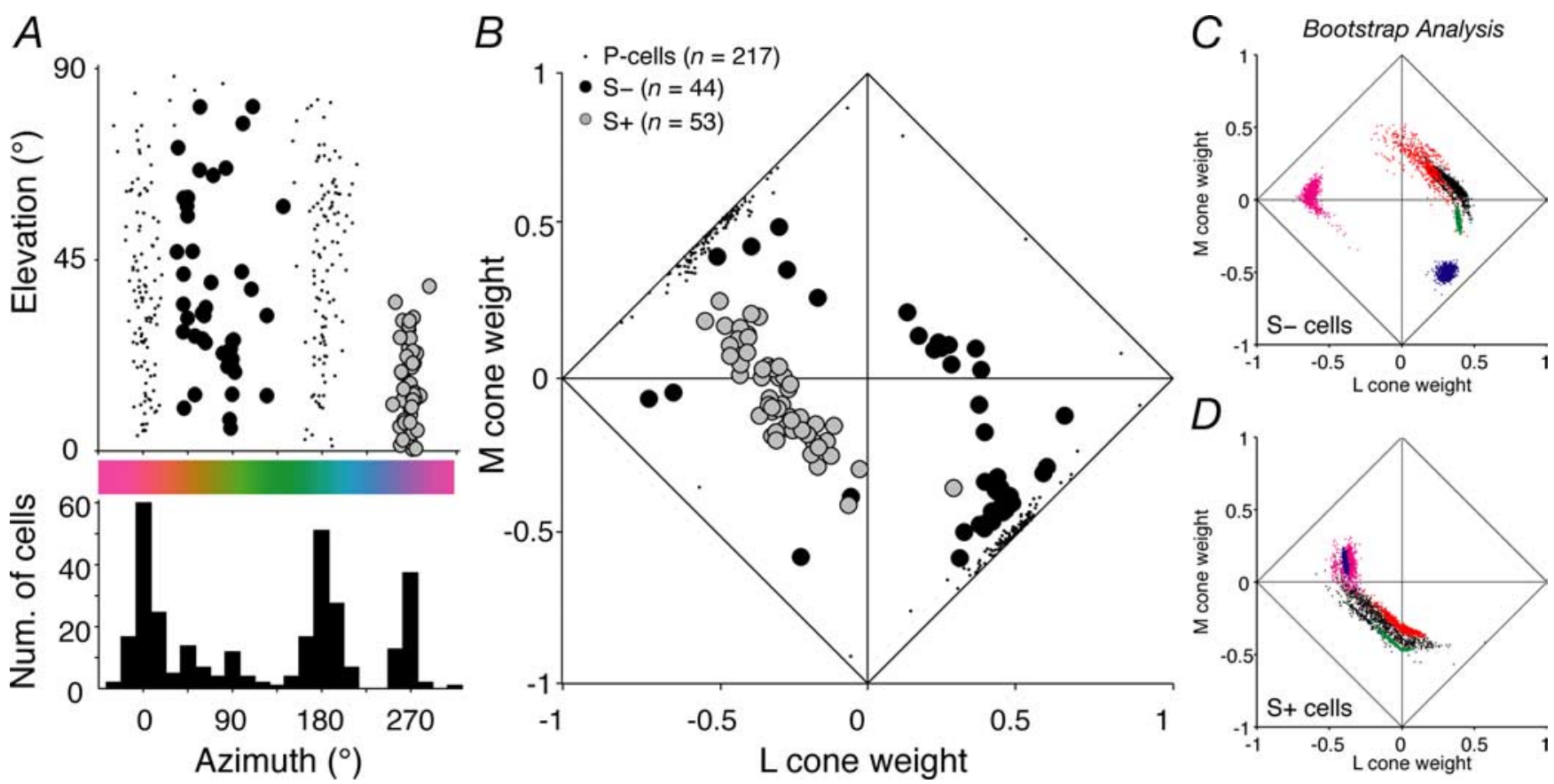

Figure 3. Chromatic signatures of $L G N$ cells. $A$, Distribution of preferred elevation and azimuth of $L G N$ cells (excluding magnocellular cells), obtained from the best-fitting predictions of the linear model described in Materials and Methods. In this plot, the sign of the elevation is ignored. Gray circles, $\mathrm{S}+$ cells; black circles, $\mathrm{S}-$ cells; dots, P-cells. The histogram underneath shows the distribution of azimuths. $\boldsymbol{B}$, The normalized weights (see Materials and Methods) assigned to each cone type by the cells in $\boldsymbol{A}$. The weight attached to M-cone input is plotted against that for the $\mathrm{L}$-cone. The distance from the diagonals reflects the magnitude of $S$-cone input (so a point at the origin has only S-cone input, one on a diagonal has no S-cone input). Mean \pm SD normalized cone weights for $S+$ cells $(S, 0.56 \pm 0.11 ; \mathrm{L},-0.29 \pm 0.14 ; \mathrm{M},-0.05 \pm 0.16 ; n=53)$ and for $\mathrm{S}-$ cells $(\mathrm{S},-0.32 \pm 0.21 ; \mathrm{L}, 0.23 \pm 0.33 ; \mathrm{M},-0.17 \pm 0.31 ; n=44)$. C, The distribution of normalized cone weights (plotted in the same space as $\boldsymbol{B}$ ) returned by fitting Equation 1 to each of 1000 bootstrap resamples of the responses of five $S-$ cells (each cell uses a different plot color). $\boldsymbol{D}$, Same as C, for five $S+$ cells.

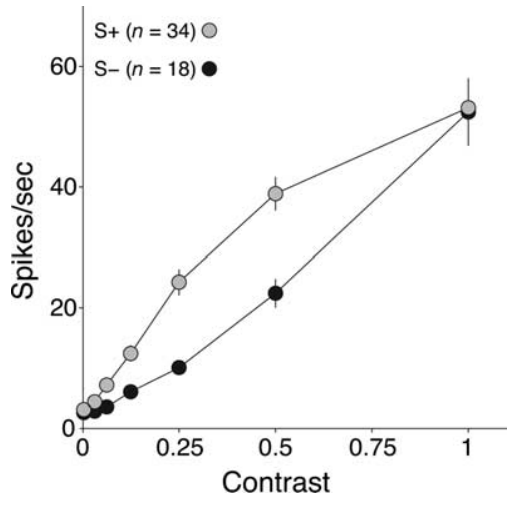

Figure 4. Contrast responses of $S+$ and $S-$ cells. The average amplitude of the modulated response of $S+$ cells ( $n=34$; gray circles) and $S-$ cells $(n=18$; black circles) to $S$-cone modulation. The stimulus was a drifting grating of preferred spatial frequency, or modulation of a spatially uniform field, at $\sim 5 \mathrm{~Hz}$. Contrast is specified relative to the maximum attainable on the monitor; 1.0 corresponds to $\sim 0.85 \mathrm{~S}$-cone contrast. Error bars (sometimes smaller than the data point) report SEMs.

gain or loss of contrast sensitivity. If we allowed only response gain to change, it was reduced by $34 \%(n=9)$; if we allowed only sensitivity to change, $c_{50}$ was increased by $40 \%$. We looked for changes in the responses of P-cells brought about by L-M habituation and found none (Fig. $5 \mathrm{C}$ ) [we have shown previously (Solomon et al., 2004) that P-cells show little habituation when driven by achromatic gratings].

To establish whether the habituation in S- cells was chromatically selective, we examined the effects of prolonged exposure to gratings of different chromaticities. Habituation to pure L-M modulation had no effect on responses to S-cone modulation
(Fig. 5D). Habituation to pure S-cone modulation or to modulation along intermediate color directions reduced responses to all directions but most for stimuli that modulated the S-cones (Fig. 5E,F). This behavior is most simply understood as arising from two mechanisms: a specific loss of sensitivity in a pathway carrying only S-cone signals, together with some slight generalized adaptation of the response. We were able to establish the retinal origin of these effects directly in four neurons for which the S-potentials that represent the excitatory input from ganglion cells (Bishop et al., 1962; Kaplan and Shapley, 1984) were clearly visible in the recordings. In all cases, the chromatic tuning of the S-potential was the same as that of the LGN neuron and was similarly affected by habituation.

\section{Spatial and temporal tuning}

The measurements described so far show that the functional characteristics of S+ and S- cells differ substantially. If this is associated with their having different morphological substrates (Dacey and Packer, 2003; Dacey et al., 2003, 2005), we might expect them to differ in the spatial organization of their S-cone inputs. We examined this by measuring spatial frequency tuning for S-isolating gratings.

Figure $6 \mathrm{~A}$ shows, separately for $\mathrm{S}+$ cells and $\mathrm{S}-$ cells encountered at comparable eccentricities (mean for $\mathrm{S}+$ cells, $15.7^{\circ}$; for $S-$ cells, $13.9^{\circ}$ ), the average spatial frequency tuning measured with S-cone-isolating gratings. For comparison, we also show the average spatial frequency tuning of P-cells encountered at comparable eccentricities, measured with achromatic gratings. S + cells were most sensitive to spatial frequencies near 0.3 cycles $/{ }^{\circ}$ and showed a reliable loss of sensitivity at lower spatial frequencies (the median response relative to peak was $0.80 ; n=31$ ). These measurements indicate that S-cone 
$A$
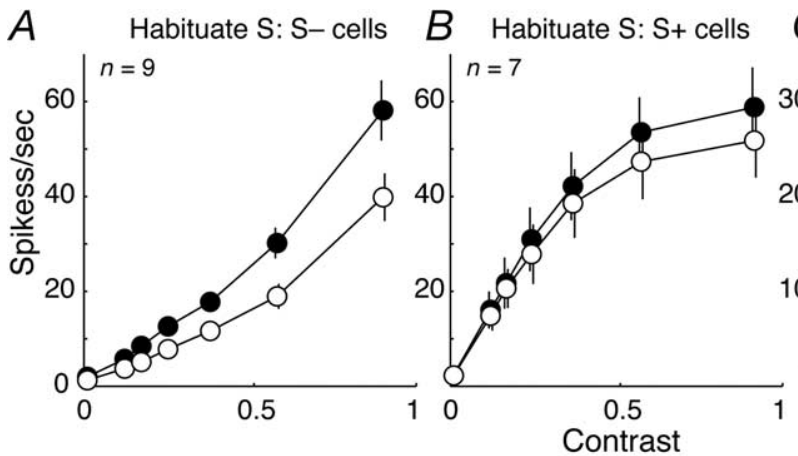

C Habituate L-M: P cells

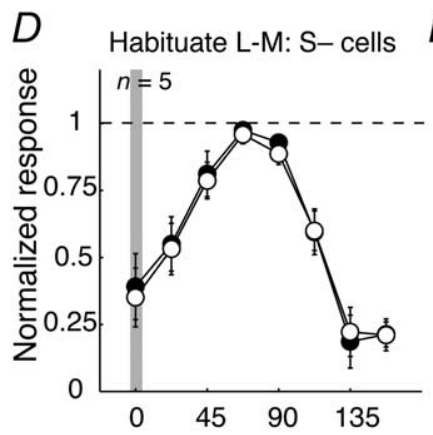

$E$ Habituate INT: S- cells

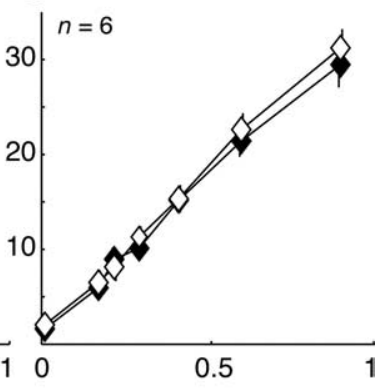

$F$ Habituate S: S- cells
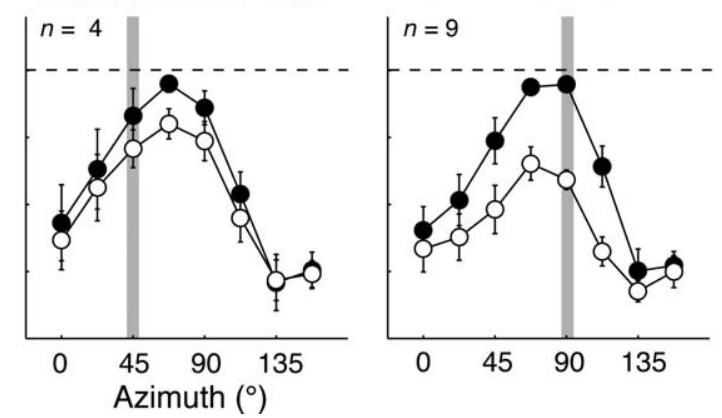

Figure 5. Impact of habituation on response. $A-C$, Average contrast response functions to isoluminant modulation obtained before (filled circles) and during (open circles) habituation to stimuli modulated along the $S$ axis $(A, B, S-$ cells and $S+$ cells, respectively) or the $L-M$ axis (C, P-cells). Contrast is specified relative to the maximum attainable modulation of the monitor (see Materials and Methods). $\boldsymbol{D}-\boldsymbol{F}$, Average color tuning of $\boldsymbol{S}$ - cells before (filled circles) and during (open circles) habituation to modulation along the $L-M$ axis $(\boldsymbol{D})$, an intermediate (INT) axis $\left(45^{\circ}, \boldsymbol{E}\right)$, and the $S$ axis $(\boldsymbol{F})$. Shaded bar in each panel denotes habituation axis. Error bars (sometimes smaller than the data point) report SEMs.

inputs to $\mathrm{S}+$ neurons are generally arranged in a spatially antagonistic manner, perhaps in center and surround. $\mathrm{S}-$ cells were substantially more sensitive to modulation of spatially uniform fields than to any grating; they responded relatively poorly to the spatial frequencies that were optimal for $\mathrm{S}+$ cells. The S-cone inputs to their receptive fields evidently lack spatial antagonism and are summed over regions much larger than is the case for $\mathrm{S}+$ cells. The distinctive differences between the curves are present at spatial frequencies below 1 cycle $/^{\circ}$. Chromatic aberration has little influence on short wavelengths at these frequencies (Marimont and Wandell, 1994); the differences must reflect a genuine difference in the spatial sampling of S-cones, because $\mathrm{S}+$ and $\mathrm{S}-$ cells were studied in the same animals across the same range of eccentricities.

In some neurons that responded well to achromatic stimuli, we also measured spatial frequency tuning with achromatic gratings. For S + cells, the curves were generally bandpass (Solomon et al., 2005; Field et al., 2007), much like those obtained with S-cone-isolating gratings (Fig. $6 B-D$ ). In $\mathrm{S}-$ neurons, the spatial frequency tuning for achromatic gratings often differed from that for S-cone-isolating gratings, generally resulting in greater sensitivity to higher frequencies and bandpass tuning. Figure $6 E-G$ show three examples.

Psychophysical measurements show that S-cone pathways have much poorer temporal resolution than do those carrying signals from L- and M-cones (Stockman et al., 1991). If this difference originates early, before signals from S-cones are brought together with those from L- and M-cones, we ought to find that the temporal tuning of $\mathrm{S}+$ and $\mathrm{S}-$ cells changes as we selectively stimulate different cone classes. We measured the temporal fre- quency sensitivity of $S+$ and $S$ - cells using S-cone-isolating modulation and achromatic modulation at the optimal spatial frequency (for S-isolating, generally uniform fields; for achromatic, gratings with median spatial frequency 1 cycle $\left./^{\circ}\right)$. Figure 7, $A$ and $B$, shows, respectively, the temporal frequency tuning for S-isolating modulation and achromatic modulation. For comparison, Figure $7 B$ also shows the average temporal tuning of $\mathrm{P}$-cells, measured with drifting achromatic gratings of the preferred spatial frequency. When driven by $\mathrm{S}$-isolating modulation, both $\mathrm{S}+$ and $S-$ cells are most sensitive to modulation near $3 \mathrm{~Hz}$; when driven by achromatic gratings, sensitivity was greatest near $7 \mathrm{~Hz}$, close to the preferred temporal frequency of P-cells. The different temporal characteristics expressed under the two conditions suggests that the relatively poor temporal resolution of the S-cone pathways originates early in the retina.

The poorer temporal resolution of Sand $\mathrm{S}+$ cells suggests that the $\mathrm{S}$-cone signals provided by them might also be delayed (relative to the $\mathrm{L}$ - and $\mathrm{M}$-cone signals provided by P-cells), but this was not the case. For each cell, we calculated the slope of the linear regression between temporal frequency and phase, at frequencies below $30 \mathrm{~Hz}$, and from this we estimated the response latency. The response latency of S+ and S- cells (estimated from S-cone-isolating modulation of low spatial frequency) did not differ from that of P-cells cells (estimated from achromatic gratings of optimal spatial frequency; S+, $59.9 \mathrm{~ms}$, $n=31$; S-, $62.1 \mathrm{~ms}, n=16$; P-cells, $61.3 \mathrm{~ms}, n=181$ ).

\section{Directional selectivity from receptive field asymmetries}

Ganglion cells driven by S-cones can have irregularly shaped receptive fields in which the S-cone inputs are substantially offset from the middle (Chichilnisky and Baylor, 1999; Field et al., 2007). If, in addition to this spatial asymmetry, the opponent mechanisms have different latencies (generally the case for receptive fields with center-surround organization) (Derrington et al., 1984; Field et al., 2007), the receptive field will be directionally selective for stimuli that excite both mechanisms (Dawis et al., 1984; Soodak, 1986). Forte et al. (2005) found that S+ cells in marmoset LGN could be directionally selective when driven by achromatic gratings.

If directional selectivity arises simply through the spatial offset of two mechanisms that have different latencies, it should disappear when the cell is driven by stimuli that isolate just one of the opponent mechanisms (through appropriate selection of stimulus chromaticity). We tested this idea in $10 \mathrm{~S}+$ and $8 \mathrm{~S}-$ cells by measuring direction tuning for drifting gratings that were achromatic or modulated only the S-cone signals or only L- and $\mathrm{M}$-cone signals (we first determined the most effective spatial and temporal frequencies for eliciting direction bias using achromatic gratings and used these parameters for the subsequent measurements). Figure $8, A$ and $B$, shows that direction selectivity is pronounced for achromatic gratings but disappears when neurons are driven by gratings that excite only S-cones or only L- and 


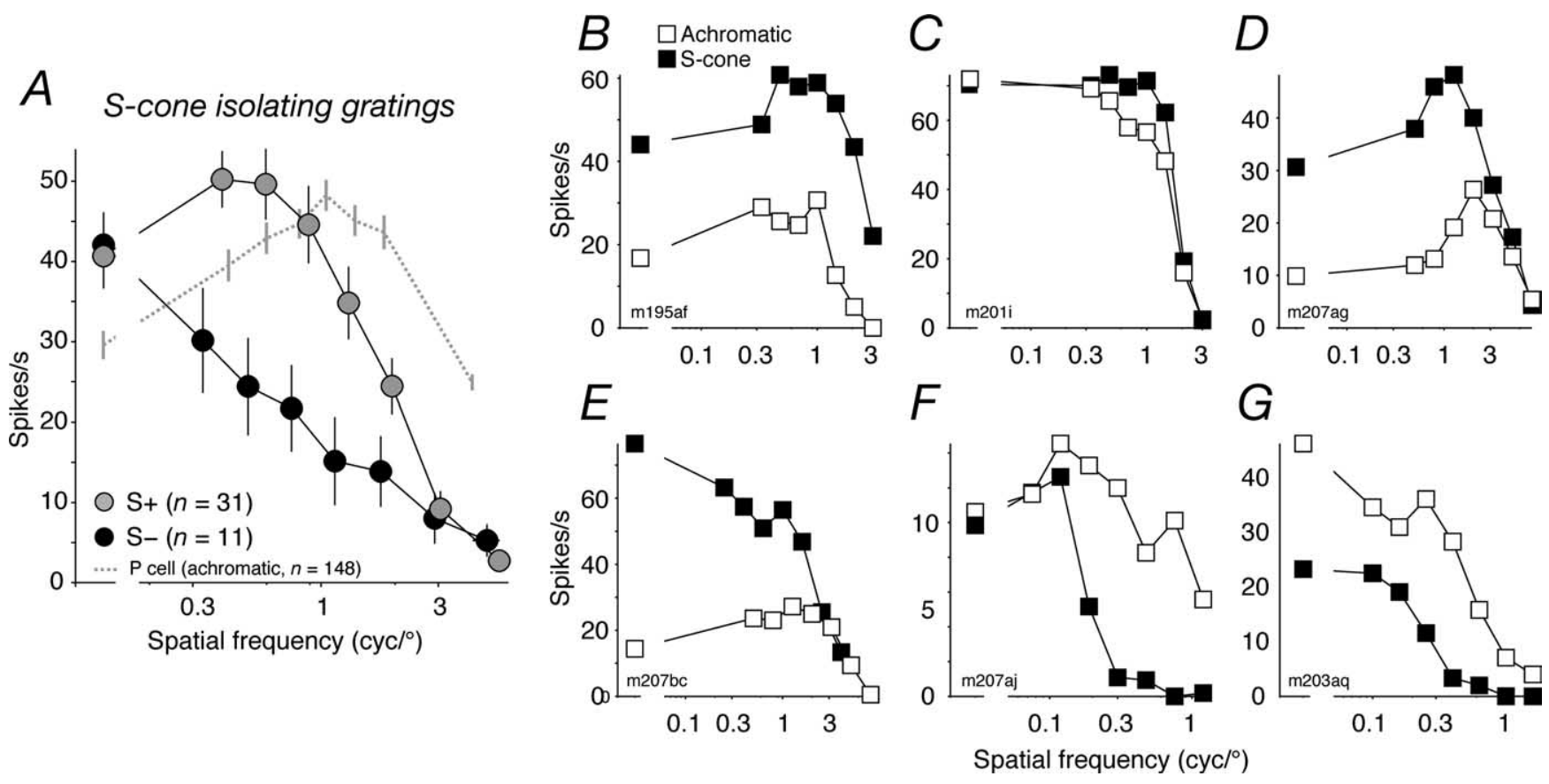

Figure 6. Spatial frequency tuning of $S+$ and $S-$ cells. $A$, Average (see Materials and Methods) spatial frequency tuning of $S+$ (gray circles) and $S-$ cells (black circles) for $S$-cone-isolating gratings. Error bars in the $x$ and $y$ (in most cases, smaller than the data point) directions report SEMs. Mean eccentricity of the $S-$ cells, $13.9^{\circ}$; of the $S+$ cells, $15.7^{\circ}$. The dashed line shows the average spatial frequency tuning of P-cells, measured with achromatic gratings (mean eccentricity of $14.3^{\circ}$ ). $\boldsymbol{B}-\boldsymbol{D}$, Spatial frequency tuning of three $S+$ cells for achromatic (open symbols) and $S$-cone isolating gratings (filled symbols). Error bars (sometimes smaller than the data point) report SEMs. $\boldsymbol{E}-\boldsymbol{G}$, Spatial frequency tuning of three $\mathbf{S}-$ cells. Conventions the same as in $\boldsymbol{B}-\boldsymbol{D}$. The leftmost (disconnected) data point in each panel shows the response to temporal modulation of a spatially uniform field.

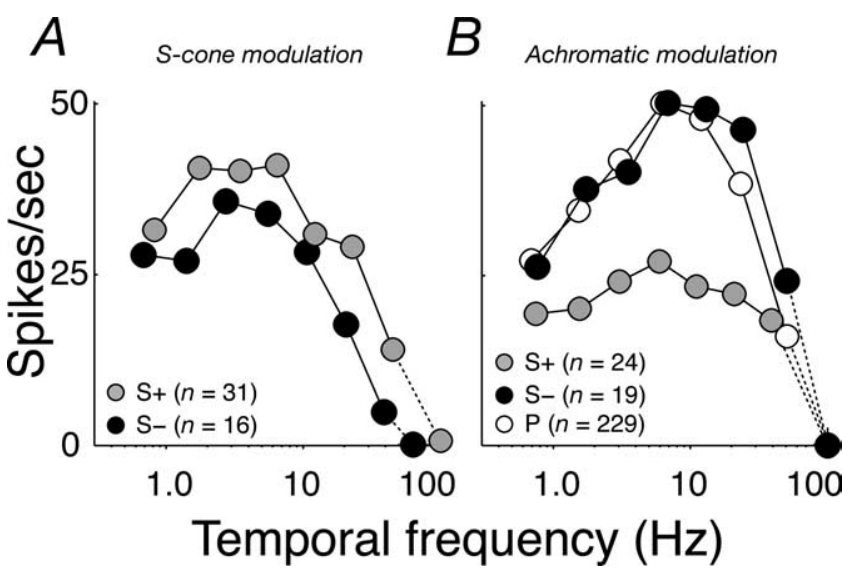

Figure 7. Temporal frequency tuning of $S+$ and $S-$ cells. $A$, Average (see Materials and Methods) temporal frequency tuning of $S+$ (gray circles) and $S$ - cells (black circles) for $S$-cone isolating modulation. $\boldsymbol{B}$, Same as $\boldsymbol{A}$ but for achromatic gratings. The average temporal frequency tuning of P-cells (open circles) for achromatic gratings is shown for comparison. Error bars in the $x$ and $y$ (in most cases, smaller than the data point) directions report SEMs.

M-cones. We quantified this with a DSI based on the circular variance (Mardia, 1972) (see Materials and Methods). This varies between 0 (no direction bias) and 1 (response to only one direction). Both S + cells (median DSI of 0.16) and S - cells (0.17) can show strong directional bias for achromatic gratings but not for S-cone gratings. It seems likely that direction biases for achromatic gratings arise from a slight spatial and temporal offset between sources of the S-cone signals and those of the L- and M-cone signals. We made no similar measurements on P- and M-cells, but previous work in other primates (White et al., 2001; $\mathrm{Xu}$ et al., 2002) suggests that their direction biases are much less prominent.
Subclasses of $S-$ cell?

The distribution of normalized S-weight among $\mathrm{S}-$ cells (Fig. $3 B$ ) departs significantly from unimodal (Hartigan's dip test, $p<$ 0.05) (Hartigan and Hartigan, 1985), suggesting that there are subtypes of S - cells. To explore this, we looked separately at other properties of cells that received an unsigned S-weight of greater than or less than 0.35 , a value that lay in the middle of the distribution of S-weight among $\mathrm{S}-$ cells. For these two groups of neurons (which had mean normalized S-weights of -0.6 and -0.2 ), Figure $9 A$ shows the contrast response, $B$ the spatial frequency tuning, and $C$ the temporal frequency tuning, all measured with $\mathrm{S}$-isolating gratings. Along these dimensions of response, there are no obvious differences between the two groups.

$\mathrm{S}-$ cells that receive $<35 \%$ of their input from S-cones might represent the tail of the distribution of S-weights among P-cells. We checked this by testing for unimodality in the distribution of normalized S-weight among all cells in Figure 3 with an unsigned S-weight $<0.35$. This distribution departed significantly from unimodality (Hartigan's dip test, $p<0.05$ ) (Hartigan and Hartigan, 1985), suggesting that the $\mathrm{S}-$ cells are not P-cells with unusually strong S-cone input.

\section{Locations in LGN}

We did not reconstruct the path of the electrode penetrations through histological sections, but we did compare the positions of isolated cells with changes in eye dominance: cells with strong $S$ input were most often encountered in the transitions between eye representations in the four dorsal layers of the LGN (laminas 3-6). These transition zones are characterized by a sharp decrease in the level of background activity picked up by the electrode (the "hash" audible when the amplified electrode signal is output through speakers). Among $42 \mathrm{~S}+$ neurons encountered in penetrations in which we could identify lamina on the basis of eye transitions, 31 were located within the transition zones. Among 


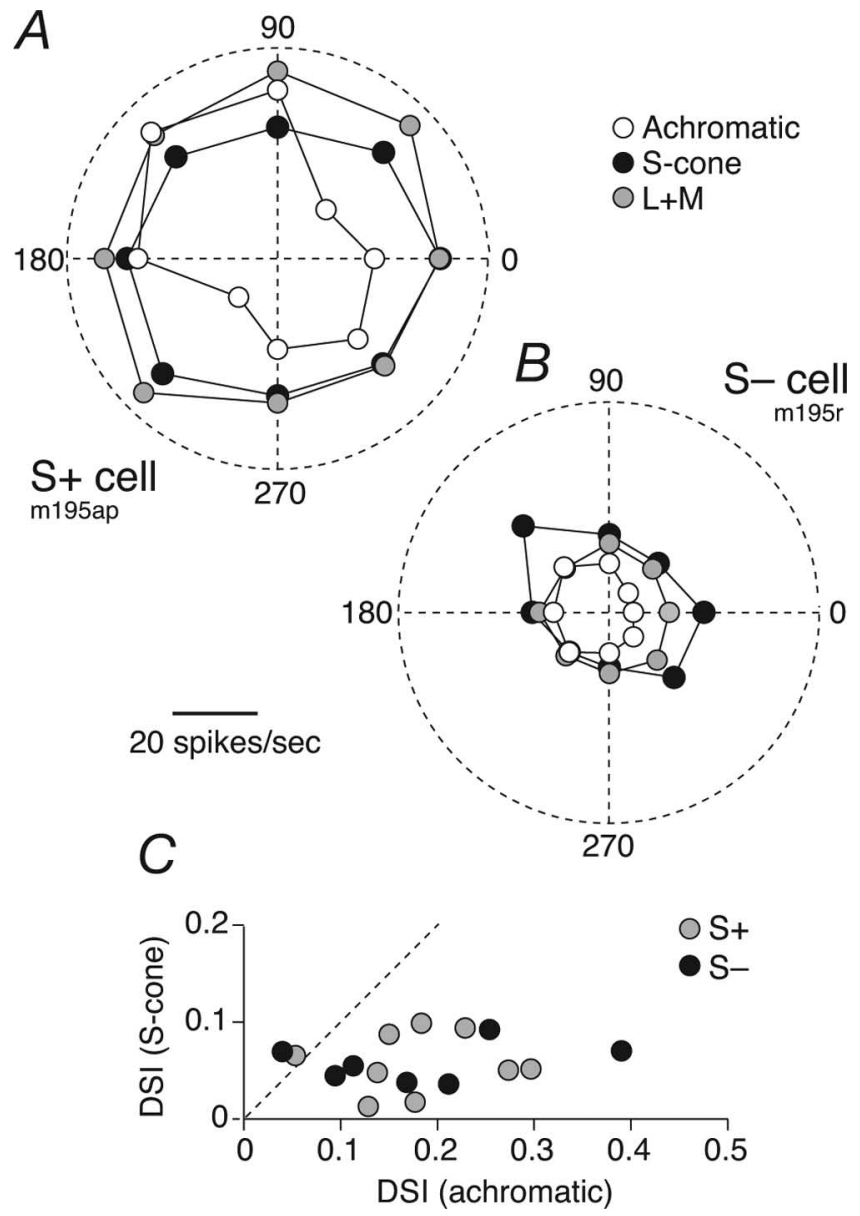

Figure 8. $S+$ and $S$ - cells show direction biases for drifting achromatic gratings. $\boldsymbol{A}$, Direction tuning of an $\mathrm{S}+$ cell to drifting gratings that were achromatic (open circles), modulated only the $S$-cones (black circles), or modulated the $L$ - and $M$-cones together ( $L+M$; gray circles). Direction of drift is indicated by angle and response amplitude by distance from the origin; 2 cycles $/{ }^{\circ}$ grating drifting at $5 \mathrm{~Hz}$. The DSIs (defined in Materials and Methods) for achromatic, $S$-cone-isolating, and $\mathrm{L}+\mathrm{M}$ gratings are $0.18,0.02$, and 0.05 , respectively. $\boldsymbol{B}$, Same as $\boldsymbol{A}$ but for an $\mathrm{S}-$ cell; 1.2 cycles/deg grating drifting at $5 \mathrm{~Hz}$. DSIs are $0.25,0.09$, and 0.02 , respectively. $\boldsymbol{C}$, Comparison of DSI for S-cone gratings and achromatic gratings for $S+$ cells and $S-$ cells.

$39 \mathrm{~S}$ - cells for which we had the same information, 33 were located within the transition zones. The remaining $\mathrm{S}+$ and $\mathrm{S}-$ cells were found among L-M opponent P-cells. Of the $\mathrm{S}-$ cells whose location we could infer, all with an unsigned $\mathrm{S}$-weight $>0.35$ were found in the transition zones, as were 18 of 24 of cells with an unsigned S-weight $<0.35$. On 11 occasions, we recorded from an $\mathrm{S}+$ and an $\mathrm{S}-$ cell located close to one another, within the same zone separating regions of differing eye dominance.

\section{Discussion}

Our characterization of S + neurons adds considerable detail to previous accounts of their properties, particularly by defining more sharply their contrast sensitivities and their spatial and temporal selectivities. S- cells, on which there has been little previous work, are quite unlike $\mathrm{S}+$ cells.

\section{Differences between $S+$ and $S-$ cells}

$\mathrm{S}+$ cells and $\mathrm{S}-$ cells differed distinctively in their chromatic preferences. The preferred directions of S+ cells were closely aligned with the $\mathrm{S}$-cone axis. Those of $\mathrm{S}-$ cells, which were much more variable, generally lay between the L-M and $\mathrm{S}$ axes (Fig. $3 A$ ), indicating that they received opposed inputs from L- and
M-cones, with that from M-cones having the same sign as the input from S-cones. This L-M opponent signature is consistent with the results of Chatterjee and Callaway (2003) who reported that $\mathrm{S}-$ cells (unlike $\mathrm{S}+$ cells) responded poorly to $\mathrm{L}+\mathrm{M}$ modulation. Among neurons in primary visual cortex that receive substantial input from S-cones, the S-cone input is often aligned with that from M-cones (Conway, 2001; Solomon and Lennie, 2005; Conway and Livingstone, 2006; Horwitz et al., 2007), possibly reflecting input from subcortical $\mathrm{S}-$ neurons.

$\mathrm{S}-$ cells differed from $\mathrm{S}+$ cells in having lower contrast sensitivity and greater susceptibility to habituation. The loss of sensitivity after habituation was substantially confined to a pathway carrying only S-cone signals, so it probably arises before the summation of cone signals in the ganglion cells. In the retinas of other species, some amacrine cells habituate (Baccus and Meister, 2002), and so do the axon terminals of some bipolar cells (Manookin and Demb, 2006); either might be the source of habituation we saw here.

The receptive fields of $\mathrm{S}-$ cells summed S-cone signals over larger regions than did those of $\mathrm{S}+$ cells (Fig. 6) (Dacey et al., 2005; Szmajda et al., 2006). S - cells, but not S + cells, sometimes showed substantially higher spatial resolution for achromatic gratings than for S-cone gratings (Fig. $6 B, C$ ), implying that they summed L- and $\mathrm{M}$-cone signals over a smaller region than $\mathrm{S}$-cone signals, although chromatic aberration could be a contributor. Thus, whereas the spatial preferences of $S+$ cells were stable to variations in chromaticity, those of $S$ - cells were not. The loss of sensitivity at lower spatial frequencies might reflect spatial antagonism in the L- and M-cone receptive field or antagonism from $\mathrm{S}$-cones that grows stronger as the spatial frequency is lowered. Measurements of spatial tuning with gratings that stimulate only $\mathrm{L}-$ and $\mathrm{M}$-cones would resolve the issue.

$\mathrm{S}+$ and $\mathrm{S}-$ cells often showed direction biases for achromatic gratings. We think it unlikely that these biases are useful for extracting the motion of surfaces: they depend on chromaticity and also on spatial and temporal frequency (data not shown). This is as expected for a receptive field in which antagonistic subregions are offset in both space and time (Dawis et al., 1984; Soodak, 1986) (see also Chichilnisky and Baylor, 1999; Field et al., 2007).

Structural basis for chromatic properties of $S+$ and $S-$ cells Our recording of $S-$ potentials suggests that the differences between $\mathrm{S}+$ and $\mathrm{S}-$ neurons arise in the retina. Dacey and colleagues (Dacey and Packer, 2003; Dacey et al., 2005) identified at least two kinds of ganglion cells that carry strong $S+$ signals and at least one type of S- cell, but the pathways that provide S-cone signals to these cells are not yet clear. Although it has long been established that a specialized bipolar cell carries $\mathrm{S}+$ signals (Mariani, 1984; Kouyama and Marshak, 1992), the existence of an S- bipolar cell remains controversial (Klug et al., 2003; Lee et al., 2005). If there is no such cell, S + signals might be inverted and provided to the ganglion cell by amacrine cells or might feed an inverting synapse on the ganglion cell. In either case, the Spathway must habituate at a point where it carries only, or preponderantly, signals from S-cones (Fig. 5). Our measurements of spatial frequency tuning (Fig. 6A) suggest that $\mathrm{S}-$ cells sum $\mathrm{S}$-cone signals over substantially larger areas than do $\mathrm{S}+$ cells.

Among S+ cells, the L- and M-cone inputs mostly have the same sign; among $\mathrm{S}-$ cells, the $\mathrm{L}$ - and $\mathrm{M}$-cone inputs mostly have opposite signs. We would like to understand these patterns, especially the observation that many $\mathrm{S}-$ cells receive excitatory input from L-cones and inhibitory input from $\mathrm{M}$ - and S-cones (Fig. 3B). This last observation hints at the existence of a mecha- 
nism that distinguishes inputs from L- and $\mathrm{M}$-cones. This is intriguing, because there is no other evidence that $\mathrm{L}$ - and $\mathrm{M}$-cones are distinguished by retinal or geniculate neurons.

We assume that $\mathrm{L}$ - and $\mathrm{M}$-cone signals reach $\mathrm{S}+$ and $\mathrm{S}-$ ganglion cells through OFF and ON bipolar cells, respectively (Dacey and Lee, 1994; Ghosh and Grunert, 1999). If the bipolar cells make indiscriminate connections with the cones that drive them, their chromatic signatures will vary with the local distribution of $\mathrm{L}-$ and $\mathrm{M}$-cones in their receptive fields; midget bipolar cells that receive excitatory drive from a single cone will be chromatically
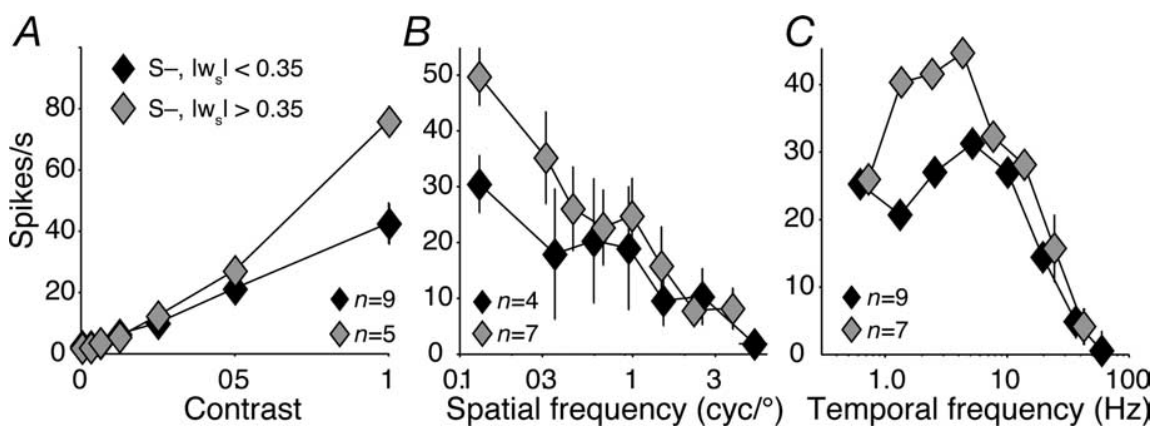

Figure 9. Properties of $S$ - cells with different proportions of S-cone input. Contrast $(\boldsymbol{A})$, spatial frequency $(\boldsymbol{B})$, and temporal frequency tuning $(\boldsymbol{C})$ of $\boldsymbol{S}$ - cells with an unsigned normalized $S$-weight greater than (gray diamonds) or less than (black diamonds) 0.35 . Stimuli were S-cone-isolating modulations. Error bars in the $x$ and $y$ (in most cases, smaller than the data point) directions report SEMs. opponent, as will many diffuse bipolar cells

that receive excitatory input from a small number of cones.

In macaque, there are $\sim 1.6$ times as many $\mathrm{L}$-cones as $\mathrm{M}$-cones (Deeb et al., 2000; Roorda et al., 2001). The excitation to midget and diffuse bipolar cells is therefore more likely to be dominated by L-cone input. Because of this L-cone dominance, when the bipolar input is opposed to that from S-cones, this translates into a bias for L-cone input to be opposed to S-cone input, with the sign of the $\mathrm{M}$-cone input determined primarily by the size of the bipolar pool. If there are many bipolar cells, the $\mathrm{L}$ and $\mathrm{M}$ signals are more likely to have the same sign (yielding $\mathrm{S}$ against $\mathrm{L}+\mathrm{M}$ ). If few bipolar cells are drawn on, their input will tend to be chromatically opponent, yielding predominantly $S$ against $\mathrm{L}-\mathrm{M}$ with the occasional $\mathrm{S}$ against $\mathrm{M}-\mathrm{L}$ signature in $\mathrm{M}$-cone dominated patches of retina. Our observations suggest that $S+$ cells accumulate $\mathrm{L}$ and $\mathrm{M}$ signals over a larger region and therefore encompass more bipolar cells than do S- cells. This is consistent with the tendency for $\mathrm{L}$ - and $\mathrm{M}$-cone inputs to be of the same sign in $\mathrm{S}+$ cells and opposed (with L against S) in S- cells. In both human (Hofer et al., 2005) and macaque (Deeb et al., 2000), the L/M cone ratio varies substantially among individuals. We expect this to contribute to the variance in cone weights in our sample.

The higher spatial resolution of some $\mathrm{S}$ - cells for achromatic versus S-isolating gratings (Fig. 6) suggests that they might be P-cells with weak S-cone input (Klug et al., 2003). We think this is unlikely on several grounds, including the distinctive placement of S - cells between LGN laminas and their susceptibility to habituation. Neither of these properties is characteristic of P-cells. Moreover, were S- cells indeed P-cells with unusual cone inputs we would expect to see modes in the distribution of preferred azimuths (Fig. $3 A$ ) at $\sim 45^{\circ}$ and $\sim 135^{\circ}$. The latter mode is entirely absent. There is also no evidence for modes at $\sim 225^{\circ}$ and $\sim 315^{\circ}$, where they would be expected were the unusual S input to P-cells just as likely to be excitatory as inhibitory.

\section{Prevalence of $\mathrm{S}+$ and $\mathrm{S}-$ cells}

Among 469 LGN neurons, we found 56 S + and 45 S-, not significantly different from the proportions we would expect were the two types equally numerous $\left(p>0.05, \chi^{2}\right.$ test). The fraction of $\mathrm{S}-$ cells greatly exceeds that reported in previous work (De Monasterio et al., 1975; Malpeli and Schiller, 1978; Derrington et al., 1984; Valberg et al., 1986). The chromatic signatures of Scells make them less obvious recipients of S-cone signals than the $\mathrm{S}+$ cells, and some might have been misclassified in previous work. The properties of our electrodes, which recorded spikes with unusually high sensitivity, probably also contributed to our finding S - cells: in the same animals, we recorded the activity of a type of LGN cell not previously described in macaque (Tailby et al., 2007).

\section{Relationship to psychophysics}

Behavioral work points to the presence of separate pathways for signaling S-cone increments and decrements (Krauskopf et al., 1982; Vassilev et al., 2003). There is evidence that the mechanism that detects S-cone decrements has lower sensitivity and a more linear contrast response than the mechanism that detects S-cone increments (Vingrys and Mahon, 1998) (but see Sakurai and Mullen, 2006), and the L- and M-cone contributions to these two mechanisms are thought to differ (McLellan and Eskew, 2000). These functional asymmetries are like those we find in the macaque LGN. The azimuth of the preferred color direction of Scells is also close to the color direction that most people call "yellow" (De Valois et al., 2000; Wuerger et al., 2005), which might be important in generating the perceptual color-opponent space characterized by Hering (1878).

\section{References}

Baccus SA, Meister M (2002) Fast and slow contrast adaptation in retinal circuitry. Neuron 36:909-919.

Bishop PO, Davis R, Burke W (1962) Interpretation of extracellular response of single lateral geniculate cells. J Physiol (Lond) 162:451.

Brainard DH (1996) Cone contrast and opponent modulation color spaces. In: Human color vision (Kaiser PK, Boynton GM, eds), Washington, DC: Optical Society of America.

Calkins DJ, Sterling P (1999) Evidence that circuits for spatial and color vision segregate at the first retinal synapse. Neuron 24:313-321.

Chatterjee S, Callaway EM (2003) Parallel colour-opponent pathways to primary visual cortex. Nature 426:668-671.

Chichilnisky EJ, Baylor DA (1999) Receptive-field microstructure of blueyellow ganglion cells in primate retina. Nat Neurosci 2:889-893.

Conway BR (2001) Spatial structure of cone inputs to color cells in alert macaque primary visual cortex (V-1). J Neurosci 21:2768-2783.

Conway BR, Livingstone MS (2006) Spatial and temporal properties of cone signals in alert macaque primary visual cortex. J Neurosci 26:10826-10846.

Dacey DM, Lee BB (1994) The "blue-on" opponent pathway in primate retina originates from a distinct bistratified ganglion cell type. Nature 367:731-735.

Dacey DM, Packer OS (2003) Colour coding in the primate retina: diverse cell types and cone-specific circuitry. Curr Opin Neurobiol 13:421-427.

Dacey D, Peterson BB, Robinson FR, Gamlin PD (2003) Fireworks in the retina. Neuron 37:15-27.

Dacey DM, Liao HW, Peterson BB, Robinson FR, Smith VC, Pokorny J, Yau KW, Gamlin PD (2005) Melanopsin-expressing ganglion cells in primate retina signal colour and irradiance and project to the LGN. Nature 433:749-754.

Dawis S, Shapley R, Kaplan E, Tranchina D (1984) The receptive field orga- 
nization of X-cells in the cat: spatiotemporal coupling and asymmetry. Vision Res 24:549-564.

de Monasterio FM (1979) Asymmetry of on- and off-pathways of bluesensitive cones of the retina of macaques. Brain Res 166:39-48.

De Monasterio FM, Gouras P, Tolhurst DJ (1975) Trichromatic colour opponency in ganglion cells of the rhesus monkey retina. J Physiol (Lond) 251:197-216.

De Valois RL, Abramov I, Jacobs GH (1966) Analysis of response patterns of LGN cells. J Opt Soc Am 56:966-977.

De Valois RL, Cottaris NP, Elfar SD, Mahon LE, Wilson JA (2000) Some transformations of color information from lateral geniculate nucleus to striate cortex. Proc Natl Acad Sci USA 97:4997-5002.

Deeb SS, Diller LC, Williams DR, Dacey DM (2000) Interindividual and topographical variation of L:M cone ratios in monkey retinas. J Opt Soc Am A Opt Image Sci Vis 17:538-544.

Derrington AM, Krauskopf J, Lennie P (1984) Chromatic mechanisms in lateral geniculate nucleus of macaque. J Physiol (Lond) 357:241-265.

Field GD, Sher A, Gauthier JL, Greschner M, Shlens J, Litke AM, Chichilnisky EJ (2007) Spatial properties and functional organization of small bistratified ganglion cells in primate retina. J Neurosci 27:13261-13272.

Forte JD, Hashemi-Nezhad M, Dobbie WJ, Dreher B, Martin PR (2005) Spatial coding and response redundancy in parallel visual pathways of the marmoset Callithrix jacchus. Vis Neurosci 22:479-491.

Ghosh KK, Grunert U (1999) Synaptic input to small bistratified (blue-ON) ganglion cells in the retina of a new world monkey, the marmoset Callithrix jacchus. J Comp Neurol 413:417-428.

Hartigan JA, Hartigan PM (1985) The dip test of unimodality. Ann Stat $13: 70-84$

Hering E (1878) Outlines of a theory of the light sense. Cambridge, MA: Harvard UP.

Hofer H, Carroll J, Neitz J, Neitz M, Williams DR (2005) Organization of the human trichromatic cone mosaic. J Neurosci 25:9669-9679.

Horwitz GD, Chichilnisky EJ, Albright TD (2007) Cone inputs to simple and complex cells in V1 of awake macaque. J Neurophysiol 97:3070-3081.

Kaplan E, Shapley R (1984) The origin of the S (slow) potential in the mammalian lateral geniculate nucleus. Exp Brain Res 55:111-116.

Klug K, Herr S, Ngo IT, Sterling P, Schein S (2003) Macaque retina contains an S-cone OFF midget pathway. J Neurosci 23:9881-9887.

Kouyama N, Marshak DW (1992) Bipolar cells specific for blue cones in the macaque retina. J Neurosci 12:1233-1252.

Krauskopf J, Williams DR, Heeley DW (1982) Cardinal directions of color space. Vision Res 22:1123-1131.

Kruger J (1977) Stimulus dependent colour specificity of monkey lateral geniculate neurones. Exp Brain Res 30:297-311.

Lankheet MJ, Lennie P, Krauskopf J (1998) Distinctive characteristics of subclasses of red-green P-cells in LGN of macaque. Vis Neurosci 15:37-46.

Lee SC, Telkes I, Grunert U (2005) S-cones do not contribute to the OFFmidget pathway in the retina of the marmoset, Callithrix jacchus. Eur J Neurosci 22:437-447.

Lennie P, Krauskopf J, Sclar G (1990) Chromatic mechanisms in striate cortex of the macaque. J Neurosci 10:649-669.

Malpeli JG, Schiller PH (1978) Lack of blue OFF-center cells in the visual system of the monkey. Brain Res 141:385-389.

Manookin MB, Demb JB (2006) Presynaptic mechanism for slow contrast adaptation in mammalian retinal ganglion cells. Neuron 50:453-464.

Mardia KV (1972) Statistics of directional data. London: Academic.

Mariani AP (1984) Bipolar cells in monkey retina selective for the cones likely to be blue-sensitive. Nature 308:184-186.

Marimont DH, Wandell BA (1994) Matching color images: the effects of axial chromatic aberration. J Opt Soc Am A 11:3113-3122.

McLellan JS, Eskew RT (2000) ON and OFF S-cone pathways have different long-wave cone inputs. Vision Res 40:2449-2465.

Merrill EG, Ainsworth A (1972) Glass-coated platinum-plated tungsten microelectrodes. Med Biol Eng 10:662-672.

Reid RC, Shapley RM (2002) Space and time maps of cone photoreceptor signals in macaque lateral geniculate nucleus. J Neurosci 22:6158-6175.

Rodieck RW (1988) The primate retina. In: Comparative primate biology, Vol 4, Neurosciences (Steklis HD, Erwin J, eds), pp 203-278. New York: Liss.
Roorda A, Metha AB, Lennie P, Williams DR (2001) Packing arrangement of the three cone classes in primate retina. Vision Res 41:1291-1306.

Sakurai M, Mullen KT (2006) Cone weights for the two cone-opponent systems in peripheral vision and asymmetries of cone contrast sensitivity. Vision Res 46:4346-4354.

Silveira LC, Lee BB, Yamada ES, Kremers J, Hunt DM, Martin PR, Gomes FL (1999) Ganglion cells of a short-wavelength-sensitive cone pathway in New World monkeys: morphology and physiology. Vis Neurosci 16:333-343.

Smith VC, Pokorny J (1975) Spectral sensitivity of the foveal cone photopigments between 400 and $500 \mathrm{~nm}$. Vision Res 15:161-171.

Smith VC, Lee BB, Pokorny J, Martin PR, Valberg A (1992) Responses of macaque ganglion cells to the relative phase of heterochromatically modulated lights. J Physiol (Lond) 458:191-221.

Snodderly DM, Handelman GJ, Adler AJ (1991) Distribution of individual macular pigment carotenoids in central retina of macaque and squirrel monkeys. Invest Ophthalmol Vis Sci 32:268-279.

Solomon SG, Lennie P (2005) Chromatic gain controls in visual cortical neurons. J Neurosci 25:4779-4792.

Solomon SG, Peirce JW, Dhruv NT, Lennie P (2004) Profound contrast adaptation early in the visual pathway. Neuron 42:155-162.

Solomon SG, Lee BB, White AJ, Ruttiger L, Martin PR (2005) Chromatic organization of ganglion cell receptive fields in the peripheral retina. J Neurosci 25:4527-4539.

Soodak RE (1986) Two-dimensional modeling of visual receptive fields using Gaussian subunits. Proc Natl Acad Sci USA 83:9259-9263.

Stockman A, MacLeod DI, DePriest DD (1991) The temporal properties of the human short-wave photoreceptors and their associated pathways. Vision Res 31:189-208.

Stockman A, Sharpe LT, Fach C (1999) The spectral sensitivity of the human short-wavelength sensitive cones derived from thresholds and color matches. Vision Res 39:2901-2927.

Szmajda BA, Buzas P, Fitzgibbon T, Martin PR (2006) Geniculocortical relay of blue-off signals in the primate visual system. Proc Natl Acad Sci USA 103:19512-19517.

Tailby C, Solomon SG, Dhruv NT, Majaj NJ, Sokol SH, Lennie P (2007) A new code for contrast in the primate visual pathway. J Neurosci 27:3904-3909.

Troy JB, Lee BB (1994) Steady discharges of macaque retinal ganglion cells. Vis Neurosci 11:111-118.

Valberg A, Lee BB, Tigwell DA (1986) Neurones with strong inhibitory $\mathrm{S}$-cone inputs in the macaque lateral geniculate nucleus. Vision Res 26:1061-1064.

Vassilev A, Mihaylova MS, Racheva K, Zlatkova M, Anderson RS (2003) Spatial summation of S-cone ON and OFF signals: effects of retinal eccentricity. Vision Res 43:2875-2884.

Vingrys AJ, Mahon LE (1998) Color and luminance detection and discrimination asymmetries and interactions. Vision Res 38:1085-1095.

White AJ, Wilder HD, Goodchild AK, Sefton AJ, Martin PR (1998) Segregation of receptive field properties in the lateral geniculate nucleus of a New-World monkey, the marmoset Callithrix jacchus. J Neurophysiol 80:2063-2076.

White AJ, Solomon SG, Martin PR (2001) Spatial properties of koniocellular cells in the lateral geniculate nucleus of the marmoset Callithrix jacchus. J Physiol (Lond) 533:519-535.

Wiesel TN, Hubel DH (1966) Spatial and chromatic interactions in the lateral geniculate body of the rhesus monkey. J Neurophysiol 29:1115-1156.

Wuerger SM, Atkinson P, Cropper S (2005) The cone inputs to the uniquehue mechanisms. Vision Res 45:3210-3223.

Xu X, Ichida J, Shostak Y, Bonds AB, Casagrande VA (2002) Are primate lateral geniculate nucleus (LGN) cells really sensitive to orientation or direction? Vis Neurosci 19:97-108.

Yeh T, Lee BB, Kremers J (1995) Temporal response of ganglion cells of the macaque retina to cone-specific modulation. J Opt Soc Am A Opt Image Sci Vis 12:456-464.

Zrenner E, Gouras P (1981) Characteristics of the blue sensitive cone mechanism in primate retinal ganglion cells. Vision Res 21:1605-1609.

Zrenner E, Nelson R, Mariani A (1983) Intracellular recordings from a biplexiform ganglion cell in macaque retina, stained with horseradish peroxidase. Brain Res 262:181-185. 